\title{
Influence of planting time and bud numbers on growth of Schefflera arboricola propagated through cutting
}

\author{
Jahanzeb Khan ${ }^{1}$, Muhammad Sajid ${ }^{1}$, Sikandar Hayat ${ }^{2 *}$, Muhammad \\ $\mathrm{Naib}^{1}$, Tayeb Muhammad ${ }^{2}$ and Kashif Hayat ${ }^{3}$ \\ 1. Department of Horticulture, University of Agricultural Peshawar, Pakistan \\ 2. College of Horticulture, Northwest A\&F University, Yangling, Shaanxi, PR China \\ 3. Department of Plant Sciences, Quaid-i-Azam University, Islamabad, Pakistan \\ *Corresponding author's email: sikander@nwsuaf.edu.cn \\ Citation \\ Jahanzeb Khan, Muhammad Sajid, Sikandar Hayat, Muhammad Naib, Tayeb Muhammad and Kashif Hayat. \\ Influence of planting time and bud numbers on growth of Schefflera arboricola propagated through cutting. \\ Pure and Applied Biology. Vol. 5, Issue 3, pp554-563. http://dx.doi.org/10.19045/bspab.2016.50071
}

\begin{tabular}{|c|c|c|c|}
\hline Received: 13/02/2016 & Revised: 02/06/2016 & Accepted: 06/06/2016 & Online First: 17/06/2016 \\
\hline
\end{tabular}

\section{Abstract}

Influence of timing and bud numbers on growth of Schefflera arboricola propagated through cutting in Peshawar was studied at Ornamental Nursery, Department of Horticulture Khyber Pakhtunkhwa Agricultural University Peshawar, during May-July 2010. The experiment was performed using Randomized Complete Block Design (RCBD) having two factors with split plot arrangement. The cuttings of Schefflera arboricola was planted on seven different dates i.e. $15^{\text {th }}$ May, $25^{\text {th }}$ May, $05^{\text {th }}$ June, $15^{\text {th }}$ June, $25^{\text {th }}$ June, $05^{\text {th }}$ July $15^{\text {th }}$ July. Four different sizes of cuttings were used in the experiments i.e. cuttings with one bud, cuttings with two, three and four buds. The planting time had significant effect on most of growth parameters. The result of the experiment showed that the Schefflera cuttings planted on $15^{\text {th }}$ July, 2010 gave maximum survival percentage $(71.19 \%)$, sprout length $(6.93 \mathrm{~cm})$, number of branch plant ${ }^{1}(3.70)$, leaf area $\left(4.80 \mathrm{~cm}^{2}\right)$, sprout thickness $(0.44 \mathrm{~cm})$, number of root plant ${ }^{1}(7.74)$, root length $(22.17 \mathrm{~cm})$ and root weight (1.24 gm). Whereas earliest sprouting (37.01 days) was observed in cuttings planted on $15^{\text {th }}$ July. The different sizes of cuttings had significant response on vegetative propagation of Schefflera through cutting. Cuttings with one bud gave best results for maximum survival percentage $(78.49 \%)$, sprout length $(7.81 \mathrm{~cm})$, number of branches plant ${ }^{1}(3.55)$, leaf area (4.91 $\left.\mathrm{cm}^{2}\right)$, sprout thickness $(0.41 \mathrm{~cm})$, number of root plant ${ }^{1}(8.16)$, root length $(21.90 \mathrm{~cm})$ and root weight (1.47 gm). Whereas, the earliest sprouting (36.82 days), was observed in cuttings having four buds. The interaction of plantings times and cuttings sizes showed that the Schefflera cuttings with one bud when planted on $15^{\text {th }}$ July, 2010 gave best results in all parameters except days to sprouting. It is concluded from the results of the experiment that the Schefflera cuttings with one bud should be planted during the mid of July under the agro-climatic condition of Peshawar, Khyber Pakhtunkhwa Pakistan.

Key words: Schefflera arboricola; Cuttings and timings; Rooting \section{Introduction}

Schefflera arboricola is a flowering plant in the family Araliaceae, native to Taiwan and Hainan (China). Its common name is "dwarf umbrella tree" and is the smaller version of the Schefflera actinophylla. It is evergreen shrub growing to 3-4 m height, often trailing stems scrambling over other vegetation. The leaves are palmate compound, with 7-9 leaflets, the leaflet 9- 
$20 \mathrm{~cm}$ long and 4-10 $\mathrm{cm}$ broad (though often smaller in cultivation). The flowers are green in color and produced in a $20 \mathrm{~cm}$ panicle of small umbels, each umbel 7-10 $\mathrm{mm}$ diameter with 5-10 flowers. It is popular for its tolerance of neglect and poor growing condition. It can be easily propagated through air layering seed and cutting takes semi-ripe stem cuttings in spring or summer. The types of cuttings include root cuttings; stem tip cutting, bud cuttings, and leaf cuttings [1] which are usually identical to the mother plant. Various plant species grows well when planted through cutting, however, the selection of cutting type depends upon the time of year, and the plant to be propagated [2]. The growth of aerial plant part exclusively depends upon the underground plant parts therefor, for normal growth and development of aerial plant parts, suitable environment should be provided to the root system [3]. For commercial cultivation of Schefflera arboricola, its factor of production needs to be investigated and standardized. The present study was conducted to observe the influence of planting time and bud numbers on growth and development of Schefflera arboricola as well as, to find out the appropriate cutting size and suitable propagation time in the agroclimatic condition of Peshawar.

\section{Materials and methods}

An experiment was conducted at Ornamental Nursery, Department of Horticulture Khyber Pakhtunkhwa Agricultural University Peshawar during May, 2010. The cuttings were planted in plastic bags in Randomized Complete Block Design (RCBD) with split plot arrangement. The experiment consisted of two factors i.e. Planting times $\left(15^{\text {th }}\right.$ May, $25^{\text {th }}$ May, $5^{\text {th }}$ June, $15^{\text {th }}$ June, $25^{\text {th }}$ June, $5^{\text {th }}$ July, $15^{\text {th }}$ July) assigned to main plot, while schefflera cuttings (One bud cuttings, Two buds cuttings, Three buds cuttings, Four buds cuttings). The data was recorded on the following parameters

\section{Days to sprouting}

The data of days to sprouting was recorded by counting the number of days from planting to $50 \%$ sprouting of cuttings.

\section{Plant survival percentage}

The plant survived at the end of the experiment was counted for all treatments in each replication and plant survival percentage was calculated with the help of the following formula:

Plant survival $(\%)=$

$$
\frac{\text { Total plant survived }}{\text { Total Number of cuttings sprouted }} \times 100
$$

\section{Sprouting length $(\mathrm{cm})$}

The sprouting length for all treatments in each replication was measured with the help of measuring tape from the point of sprout to the top of the branch and average was obtained.

\section{Number of branch plant ${ }^{1}$}

The total numbers of branches for all treatments were counted and the average was calculated.

\section{Leaf area $\left(\mathrm{cm}^{2}\right)$}

Leaf area was measured with help of leaf area meter for all treatments in each replication and average was measured.

\section{Sprout thickness (cm)}

Sprout thickness of five randomly selected plants was measured with the help of Vernier caliper for all treatments in each replication and average was calculated.

\section{Number of root plant ${ }^{1}$}

Number of root plant ${ }^{1}$ was counted for all treatments in each replication and the average number of roots plant $^{1}$ was counted.

\section{Primary root length plant $\mathbf{t}^{1}(\mathrm{~cm})$}

Primary root length plant ${ }^{1}$ was measured with the help of measuring tape and the average length of root plant ${ }^{1}$ was calculated.

\section{Root weight (gm)}

The root was properly washed with tape water and cut off from the plant and then was weighed for all treatments in each replication with help of electrical balance and average root weight plant $^{-1}$ was calculated. 


\section{Statistical analysis}

The results were statistically analyzed using SPSS 16.0. Analysis of variance (ANOVA) was performed to determine significant differences. Mean separation was carried out by the Least Significant Difference test (LSD).

\section{Results and discussions \\ Days to sprouting}

The analysis of variance showed that different sizes of cuttings and times had significant effect on the days to sprouting while their interaction had a nonsignificant effect (Table 1). Comparing the mean values for cuttings it is clear from the table that the maximum days to sprouting (42.02) were taken by cutting having one bud, followed by cuttings with two buds (39.91), while minimum days to sprouting (36.82) was recorded in cuttings with four buds. On the other hand, different times showed a significant effect on days to sprouting. However, maximum days to sprouting (41.05) was observed in cuttings planted on $15^{\text {th }}$ June, followed by cuttings planted on $25^{\text {th }}$ June (40.20), While minimum days to sprouting (37.01) was recorded for cuttings planted on $15^{\text {th }}$ July, 2010. It is revealed form the data that early sprouting was observed in cuttings with four buds and late sprouting in cuttings with one bud which may be due to the more reserve food in cuttings with four buds and less in cuttings with one bud. The data regarding the effect of different planting times revealed that the early and late sprouting were achieved in $15^{\text {th }}$ July and $15^{\text {th }}$ June plantation respectively. These result showed, that the cuttings planted on $15^{\text {th }}$ July got the favorable environment conditions with high humidity as compared to cutting planted on $15^{\text {th }}$ June.

\section{Survival percentage $(\%)$}

Statistical analysis of data showed that cuttings and times had significant effect on percent plant survival while their interaction had non-significant effect on plant survival percentage (Table 1). It is the evident from the mean table that maximum survival percentage $(78.49 \%)$ was obtained in cuttings with one bud, followed by cuttings with two buds (63.97 $\%$ ), while minimum survival percentage $(53.42 \%)$ was recorded in cuttings with four buds. On the other hand, the times had significant effect on percent plant survival, however, maximum survival percentage $(71.19 \%)$ was observed in cuttings planted on $15^{\text {th }}$ July followed by cuttings planted on $05^{\text {th }}$ July $(66.85 \%)$, while minimum survival percentage (59.96 $\%$ ) was observed in cuttings planted on $15^{\text {th }}$ June. It is revealed from the data that percent sprouting was more in cuttings with one bud and minimum in cuttings with four buds, which collaborates with maximum and minimum percent plant survival in cuttings with one bud and cuttings with four buds respectively. Which means that survival is in direct relation with sprouting and is possible that the cuttings with one bud having more sprouting will have higher survival as well. Because improved and faster sprouting, created cooperated competition among the plants for light, water and nutrients and resulted in increased percent plant survival. These results showed that the cuttings planted on $15^{\text {th }}$ July got the favorable environmental conditions with high humidity, temperature and partial shade as compared to cuttings planted on $15^{\text {th }}$ June, 2010. This can be justified as the environmental condition pertaining to survival was favorable for the cuttings with one bud planted on $15^{\text {th }}$ July while it is less favorable for cuttings with four buds and three buds. Yong and Kisum, [4] reported that planting time and types of cuttings had a significant effect on propagation of America sycamore in terms of survival percentage (\%) and percent sprouting (\%). The cuttings of bougainvillea also showed best result for the most of the parameters when planted in the month of July [5]. 
Table 1. Effect of timing and bud numbers on days to sprouting, survival percentage (\%) and sprout length $(\mathrm{cm})$ of Schefflera propagated through cutting

\begin{tabular}{|c|c|c|c|}
\hline Parameters & $\begin{array}{l}\text { Days to } \\
\text { sprouting }\end{array}$ & $\begin{array}{l}\text { Survival } \\
\text { percentage }(\%)\end{array}$ & $\begin{array}{l}\text { Sprout length } \\
\text { (cm) }\end{array}$ \\
\hline \multicolumn{4}{|l|}{ Schefflera cuttings (C) } \\
\hline Cuttings with One bud & $42.02 \mathrm{a}$ & 78.49 a & $7.81 \mathrm{a}$ \\
\hline Cuttings with Two buds & $39.91 \mathrm{~b}$ & $63.97 \mathrm{~b}$ & $6.50 \mathrm{~b}$ \\
\hline Cuttings with Three buds & $38.93 \mathrm{c}$ & $58.77 \mathrm{c}$ & $5.86 \mathrm{c}$ \\
\hline Cuttings with Four buds & $36.82 \mathrm{~d}$ & $53.42 \mathrm{~d}$ & $5.19 \mathrm{~d}$ \\
\hline LSD values & 0.500 & 3.882 & 0.353 \\
\hline \multicolumn{4}{|l|}{ Planting time (P) } \\
\hline $15^{\text {th }}$ May & $39.28 \mathrm{c}$ & $62.53 \mathrm{c}$ & $6.43 \mathrm{abc}$ \\
\hline $25^{\text {th }}$ May & $39.79 \mathrm{bc}$ & $62.34 \mathrm{c}$ & $6.46 \mathrm{abc}$ \\
\hline $05^{\text {th }}$ June & $40.02 \mathrm{~b}$ & $60.68 \mathrm{c}$ & $6.28 \mathrm{bcd}$ \\
\hline $15^{\text {th }}$ June & $41.05 \mathrm{a}$ & $59.96 \mathrm{c}$ & $5.83 \mathrm{~d}$ \\
\hline $25^{\text {th }}$ June & $40.20 \mathrm{~b}$ & $62.08 \mathrm{c}$ & $5.96 \mathrm{~cd}$ \\
\hline $05^{\text {th }}$ July & $38.50 \mathrm{~d}$ & $66.85 \mathrm{~b}$ & $6.48 \mathrm{ab}$ \\
\hline $15^{\text {th }}$ July & $37.01 \mathrm{e}$ & $71.19 \mathrm{a}$ & $6.93 \mathrm{a}$ \\
\hline LSD values & 0.6901 & 4.189 & 0.500 \\
\hline \multicolumn{4}{|l|}{ Interaction $(\mathbf{C} \times \mathbf{P})$} \\
\hline LSD values & NS & NS & NS \\
\hline
\end{tabular}

The dissimilar letters in each column indicate significant differences between them in $5 \%$ level of probability using LSD

\section{Sprouting length $(\mathrm{cm})$}

The analysis of variance showed that different cuttings and times had significant effect on sprouting length while their interaction had a non-significant effect (Table 1). Comparing the mean values for cuttings, it is clear from the table that the maximum sprouting length $(7.81 \mathrm{~cm})$ was observed in cutting with one bud, followed by cuttings with two buds $(6.50 \mathrm{~cm})$, whereas, minimum sprouting length (5.19 $\mathrm{cm}$ ) was recorded in cuttings with four buds. Moreover, the mean values of different times showed significant effect on sprouting length, however, maximum sprouting length $(6.93 \mathrm{~cm})$ was obtained in cutting planted on $15^{\text {th }}$ July which is statistically at par with cuttings planted on $05^{\text {th }}$ July $(6.48 \mathrm{~cm})$, while minimum sprouting length $(5.83 \mathrm{~cm})$ was recorded for cuttings planted on $15^{\text {th }}$ June. The increased in sprouting length in cutting with one bud may be due to maximum number of roots and root length which resulted in more photosynthesis and more nutrients and water absorption. The maximum sprouting length gained by cuttings with one bud planted on $15^{\text {th }}$ July could be attributed to the fact that the plant got maximum aerial as well as underground growth which was favored by optimum environmental conditions and also helped in development and faster sprouting. While minimum sprouting length attained by cuttings with four buds planted on $15^{\text {th }}$ June can be attributed to less favorable environmental conditions. This work is also in agreement with Jurgen and Kristian, [6] who reported that an increase in the number of roots in Schefflera, achieved with increasing the cutting position on the stock plant (measured from top to base) or with increasing stem length below the node, accelerated the onset of auxiliary bud growth and resulted in an increase in 
sprout length.

\section{Number of branches plant ${ }^{-1}$}

The analysis of variance revealed that different cuttings and times had a significant effect regarding this parameter while the interaction had non-significant effect on the number of branches plant ${ }^{-1}$ (Table 2). Comparing the mean values of cuttings, it is evident from the table that maximum number of branches plant ${ }^{-1}$ (3.55) was counted in cuttings with one bud followed by cuttings with two buds (3.00), while cuttings with four buds produced minimum number of branches plant $^{-1}$ (2.49). Different times had also significant effect on number of branches plant $^{-1}$. It is cleared from the table that maximum number of branches plant $^{-1}$ (3.70) were recorded for cutting planted on $15^{\text {th }}$ July followed cuttings planted on $05^{\text {th }}$ July (3.58), while minimum number of branches plant $^{-1}(2.35)$ were recorded in cuttings planted on $15^{\text {th }}$ June. As it is evident that more length was gained by cuttings with one bud and less sprout length was noted for cuttings with four buds. Similarly, the maximum and minimum number of branches plant ${ }^{1}$

Table 2. Effect of timing and bud numbers on number of branches plant ${ }^{-1}$, leaf area $\left(\mathrm{m}^{-2}\right)$ and sprout thickness $(\mathrm{cm})$ of Schefflera propagated through cutting

\begin{tabular}{|c|c|c|c|}
\hline Parameters & Number of branches plant ${ }^{-1}$ & Leaf area $\left(\mathrm{m}^{-2}\right)$ & Sprout thickness (cm) \\
\hline \multicolumn{4}{|l|}{ Schefflera cuttings (C) } \\
\hline Cuttings with One bud & $3.55 \mathrm{a}$ & $4.91 \mathrm{a}$ & $0.41 \mathrm{a}$ \\
\hline Cuttings with Two buds & $3.00 \mathrm{~b}$ & $3.95 \mathrm{~b}$ & $0.38 \mathrm{~b}$ \\
\hline Cuttings with Three buds & $2.70 \mathrm{bc}$ & $3.33 \mathrm{c}$ & $0.34 \mathrm{c}$ \\
\hline Cuttings with Four buds & $2.49 \mathrm{c}$ & $2.83 \mathrm{~d}$ & $0.34 \mathrm{c}$ \\
\hline LSD values & 0.308 & 0.308 & 0.027 \\
\hline \multicolumn{4}{|l|}{ Planting time (P) } \\
\hline $15^{\text {th }}$ May & $3.06 \mathrm{~b}$ & $3.92 \mathrm{bc}$ & $0.38 \mathrm{~b}$ \\
\hline $25^{\text {th }}$ May & $2.68 \mathrm{bc}$ & $3.58 \mathrm{~cd}$ & $0.36 \mathrm{bc}$ \\
\hline $05^{\text {th }}$ June & $2.61 \mathrm{c}$ & $3.22 \mathrm{de}$ & $0.33 \mathrm{~cd}$ \\
\hline $15^{\text {th }}$ June & $2.35 \mathrm{c}$ & $2.73 \mathrm{e}$ & $0.31 \mathrm{~d}$ \\
\hline $25^{\text {th }}$ June & $2.58 \mathrm{c}$ & $3.78 \mathrm{bcd}$ & $0.36 \mathrm{bc}$ \\
\hline $05^{\text {th }}$ July & $3.58 \mathrm{a}$ & $4.28 \mathrm{ab}$ & $0.39 \mathrm{~b}$ \\
\hline $15^{\text {th }}$ July & $3.70 \mathrm{a}$ & $4.80 \mathrm{a}$ & $0.44 \mathrm{a}$ \\
\hline LSD values & 0.432 & 0.666 & 0.035 \\
\hline \multicolumn{4}{|c|}{ Interaction $(\mathbf{C} \times \mathbf{P})$} \\
\hline LSD values & NS & NS & 0.072 \\
\hline
\end{tabular}

The dissimilar letters in each column indicate significant differences between them in 5\% level of probability using LSD recorded for the same cuttings respectively. The different means values for different times of plantation revealed that maximum number of branches plant ${ }^{1}$ were produced by the cuttings, planted on $15^{\text {th }}$ July, while minimum were produced by the cuttings planted on $15^{\text {th }}$ June, which can be justified as, $15^{\text {th }}$ July plantation produced more number of roots, resulted in more number of branches because they received the optimum environment, while plantation on $15^{\text {th }}$ June produced less number of roots which resulted in less number of branches as they might have less favorable environmental condition. This work is an agreement with Hussein, [7] who reported that Thunbergia grandiflora cuttings planted in month of July produced maximum number of branches and leaves. $\mathrm{He}$ also recommended that the early planting date (July 21) was positive in improving stem diameter, vegetative and root growth. He recommended that the early planting date July 21 was positive in improving the rooting and the vegetative growth of Thunbergia grandiflora stem cuttings. 


\section{Leaf area $\left(\mathrm{cm}^{2}\right)$}

The analysis of variance revealed that different cuttings and times had significant effect on leaf area while their interaction had non-significant effect (Table 2). Comparing the means values for different cutting it is cleared from the table that the maximum leaf area $\left(4.91 \mathrm{~cm}^{2}\right)$ was recorded in cuttings with one bud followed by cuttings with two buds $\left(3.95 \mathrm{~cm}^{2}\right)$, while minimum leaf area $\left(2.83 \mathrm{~cm}^{2}\right)$ was observed for cuttings with four buds. The planting time also had significant effect on leaf area. The cuttings planted on $15^{\text {th }}$ July, 210 had maximum leaf area $\left(4.80 \mathrm{~cm}^{2}\right)$, followed by cuttings planted on $05^{\text {th }}$ July having leaf area $\left(4.28 \mathrm{~cm}^{2}\right)$, while minimum leaf area $\left(2.73 \mathrm{~cm}^{2}\right)$ was recorded for cuttings planted on $15^{\text {th }}$ June. The maximum leaf area gained by cuttings with one bud may be attributed to maximum aerial and underground growth attained by cutting which resulted in more nutrients uptake and photosynthates accumulation and hence contributed in increased leaf area. The maximum leaf area observed in cuttings with one bud planted on $15^{\text {th }}$ July might be attributed to favorable environment for vigorous growth, resulted more leaf area for cutting. This work is in agreement with Acker and Leutscher, [8] who reported that the single node cuttings of Schefflera were longer in length, had fewer leaves and hence more leaf area.

\section{Sprout thickness (cm)}

The analysis of variance revealed that different cuttings, times and their interaction had significant effect on sprout thickness $(\mathrm{cm})$ of Schefflera cuttings (Table-2). Comparing the means values for different cuttings it is clear from the table that the cuttings with one bud had maximum sprout thickness $(0.41 \mathrm{~cm})$ followed by cuttings with two buds ( 0.38 $\mathrm{cm})$, whereas, cuttings with four buds had minimum sprout thickness $(0.34 \mathrm{~cm})$. The times effect is also significant and cuttings planted on $15^{\text {th }}$ July had maximum sprout thickness $(0.44 \mathrm{~cm})$, followed by $05^{\text {th }} \mathrm{July}$
$(0.39 \mathrm{~cm})$ plantation, while minimum sprout thickness $(0.31 \mathrm{~cm})$ was recorded in cuttings planted on $15^{\text {th }}$ June. The interaction effect was significant, however the maximum sprout thickness $(0.48 \mathrm{~cm})$ was recorded in cuttings with one bud planted on $15^{\text {th }}$ July followed by cuttings with one bud planted on $05^{\text {th }}$ July $(0.39$ $\mathrm{cm}$ ), while minimum sprout thickness $(0.25 \mathrm{~cm})$ recorded cuttings with four buds planted on $15^{\text {th }}$ June (Fig 1). The maximum sprout thickness of cuttings with one bud may be attributed to the sprouting length, more number of roots and leaves. Similarly, different mean values for different timings revealed that maximum sprout thickness was recorded in cuttings with one bud, planted on $15^{\text {th }}$ July, the probable reason might be the high humidity optimum temperature and receiving better light. As cuttings with one bud produced more number of leaves so greater exposure to the sun having more leaf area etc and hence more food is available for plant, that is why sprout thickness is more in cuttings with one bud as compared to the other sizes of cuttings. This work is in agreement with Zanin and Ponchia, [9] who reported that Schefflera grown on sludge-compost + peat $(1: 1)$ gave the best results as regard to vegetative growth and marketable value. This work is also in agreement with Hussein, [7] who reported that cuttings planted on July 21, produced significant increase in rooting percentage, number of roots as well as number of branches and stem diameter of Thunbergia grandiflora. The early planting was positive in improving the rooting and the vegetative growth on Thunbergia grandiflora stem cuttings.

\section{Number of roots plant ${ }^{1}$}

The analysis of variance showed that the times as well as cuttings and their interaction significantly affected the number of roots plant ${ }^{1}$ of Schefflera (Table-3). Comparing the means values for different cuttings it is clear from the table that the cuttings with one bud had 
maximum number of roots plant $^{1}$ (8.16), followed by cuttings with two buds (7.03), whereas, cuttings with four buds had minimum number of roots plant ${ }^{1}$ (6.14). The times affect is also significant and cuttings planted on $15^{\text {th }}$ July had maximum number of roots plant ${ }^{1}$ (7.74), followed by $05^{\text {th }}$ July (7.55) plantation, while minimum number of roots plant ${ }^{1}$ (6.37) was recorded in cuttings planted on $15^{\text {th }}$ June. The interaction effect was significant. However, the maximum number of roots plant $^{1}$ (9.87) was recorded in cuttings with one bud planted on $15^{\text {th }} \mathrm{July}$, followed by cuttings with one bud planted on $05^{\text {th }}$ July (8.77), while minimum number of roots plant $^{1}$ (5.93) was recorded in cuttings with four buds planted on $25^{\text {th }}$ June (Fig 2). The more number of leaves in cuttings with one bud may be attributed to the maximum aerial growth like sprout length and stem thickness which might lead to enhanced photosynthesis and ultimately resulted in maximum number of roots. The minimum number of roots in cuttings with four buds may be attributed to the minimum values of the above mentioned parameters. As for as the times effect are concerned the maximum roots were produced by cuttings, planted on $15^{\text {th }}$ July and minimum were recorded for the cuttings planted on $15^{\text {th }}$ June respectively, because the $15^{\text {th }}$ July plantation got maximum survival, sprout length and sprout thickness due to favorable environment which finally resulted into maximum aerial as well as underground growth. In interaction number of roots were maximum for the cuttings with one bud planted on $15^{\text {th }}$ July, while it was minimum for the cuttings with four buds planted on $15^{\text {th }}$ June which may be attributed to the already, mentioned factors as well as to the response of different cuttings to different environment. The present findings are in agreement with the Yadav et al, [10] who stated that planting of bougainvillea species on $15^{\text {th }}$ July gave the best result in terms of percent cuttings rooted $(90 \%)$ and number of roots per cuttings. This work is also in agreement with Racek and Kertesze [11] who reported that the nodal softwood cuttings of clematis produced an average of $84-92$ $\%$ roots.

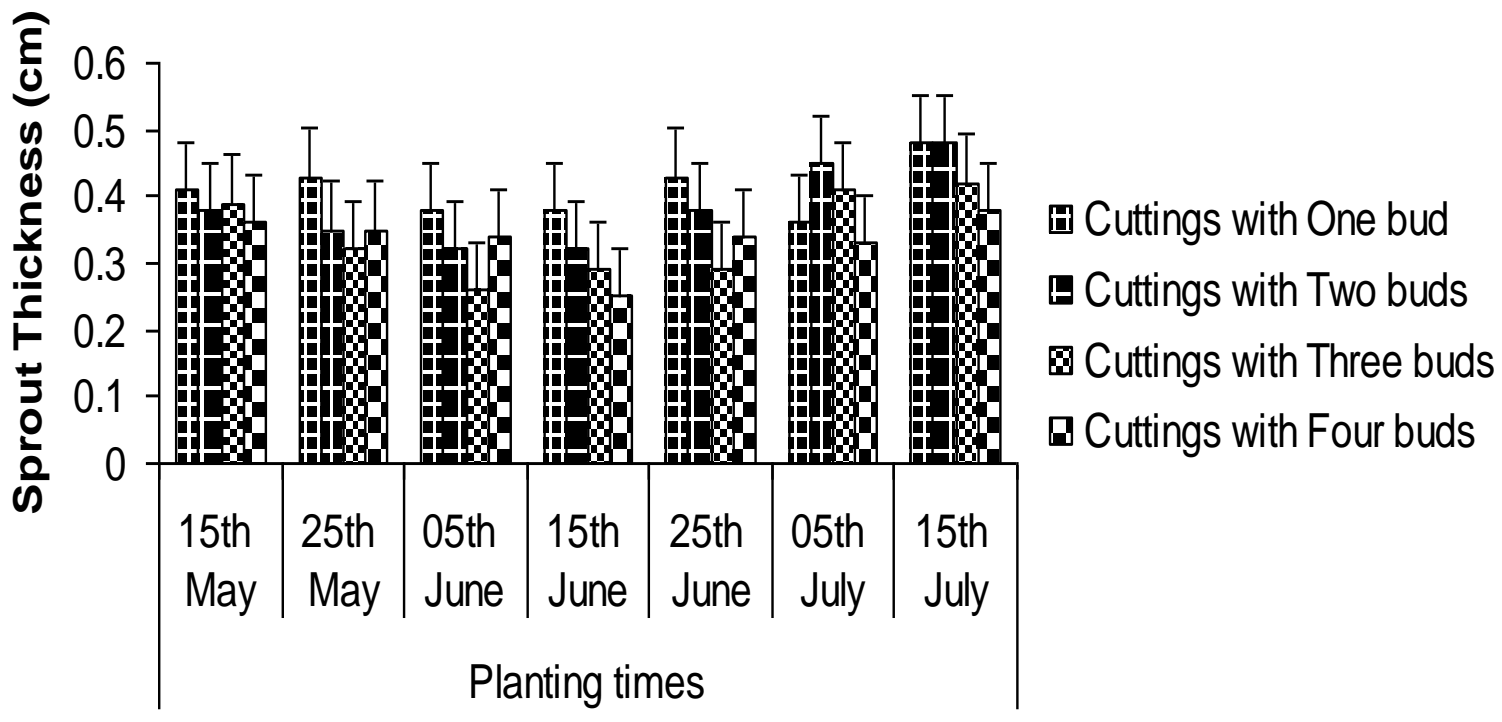

Figure 1. Sprout thickiness $(\mathrm{cm})$ of Schefflera propagated through cutting 


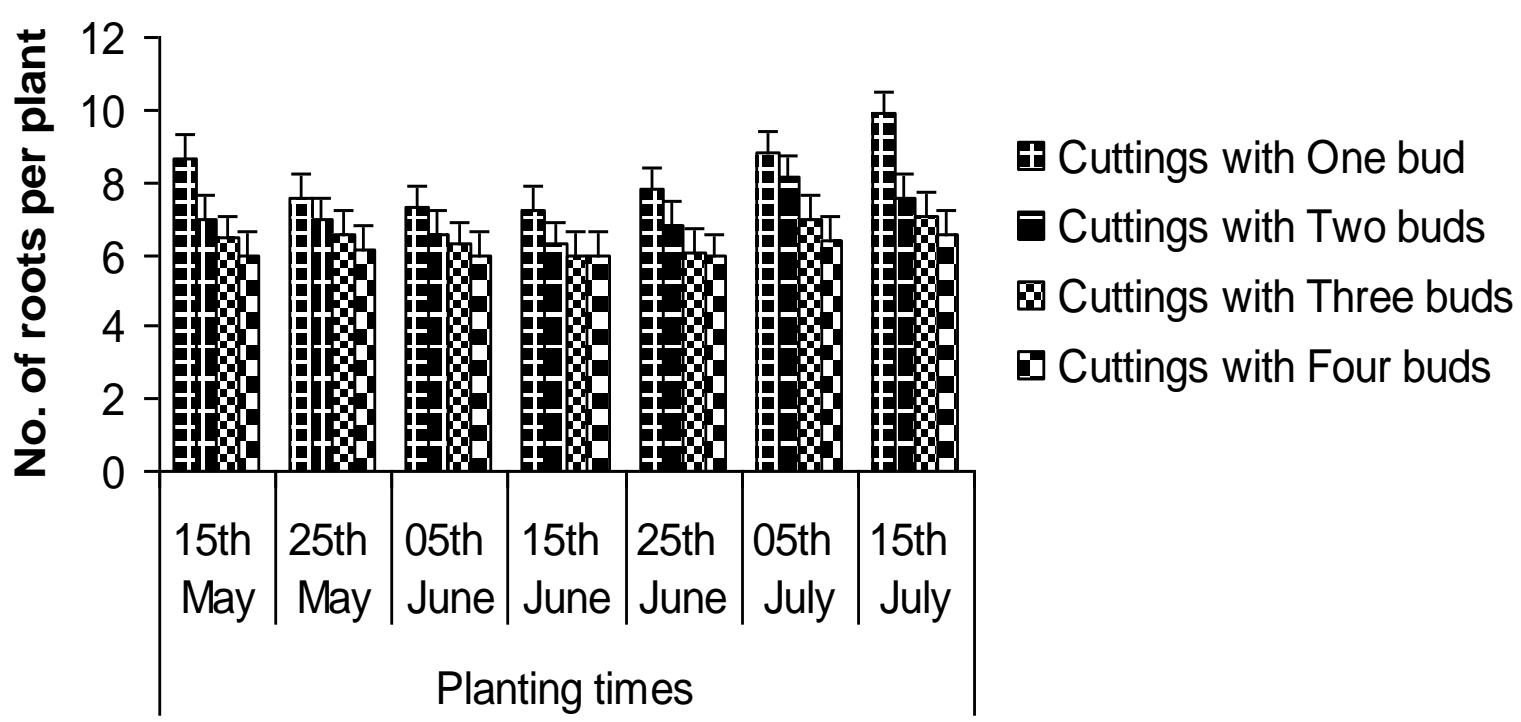

Figure 2. Number of root per plant of Schefflera propagated through cutting

\section{Primary root length $(\mathrm{cm})$}

The analysis of variance revealed that different cuttings, times and their interaction had significant effect on primary root length of Schefflera cuttings (Table-3). Comparing the means values for different cuttings it is cleared from the table that the cuttings with one bud had maximum root length $(21.90 \mathrm{~cm})$, followed by cuttings with two buds (19.93 $\mathrm{cm})$, whereas, cuttings with four buds had minimum root length $(15.02 \mathrm{~cm})$. The times effect is also significant and cuttings planted on $15^{\text {th }}$ July had more root length $(22.17 \mathrm{~cm})$, followed by $05^{\text {th }}$ July $(21.21$ $\mathrm{cm})$ plantation, while minimum root length $(16.38 \mathrm{~cm})$ was recorded in cuttings planted on $15^{\text {th }}$ June. The interaction of cuttings and time also significantly influenced the primary root length. However, the maximum root length (27.93 $\mathrm{cm})$ was recorded in cuttings with one bud planted on $15^{\text {th }}$ July followed by same cutting $(25.20 \mathrm{~cm})$ planted on $25^{\text {th }}$ May. While less root length $(11.0 \mathrm{~cm})$ was recorded in cuttings planted on $25^{\text {th }}$ June having four buds (Fig 3). The maximum root length in cuttings with one bud may be attributed to vigorous vegetative growth of the cuttings, their better adaptation to the climatic condition while the minimum value for cuttings with four buds might be due to the low vigor and less number of leaves, branches and less vigor because deeper and vigorous roots are necessary for the plant having vigorous canopy, which may fix the plant into the medium and vice versa. The interaction effect revealed that the maximum and minimum root length were recorded for the cuttings with one bud planted on $15^{\text {th }}$ July and cuttings with four buds planted on $15^{\text {th }}$ June respectively. This may be attributed as the cuttings with one bud are vigorous and when planted on $15^{\text {th }}$ July received optimum climatic condition for root growth, while the minimum root length attained by cuttings with four buds when planted on $15^{\text {th }}$ June may be due to small canopy of plants and cuttings response to different environmental conditions. This work is in agreement with the work of Yadav et al., [10] who stated that the planting of bougainvillea species planted on $15^{\text {th }}$ July gave the best result in terms of percent rooted (90\%), number of roots plant ${ }^{1}$ and root length. This work is also in agreement with Elgimabi, [12] who reported that the (Ixora coccina) cuttings planted in summer season gave best result 
in number of roots and root length.

\section{Root weight (gm)}

The analysis of variance revealed that different cuttings and times had significant effect on root weight while their interaction had non-significant effect (Table-9). Means of different times revealed that maximum root weight (1.24 g) was observed in the cuttings planted on $15^{\text {th }}$ July, followed by the cuttings planted on $05^{\text {th }}$ July $(0.98 \mathrm{~g})$, while minimum root weight $(0.74 \mathrm{~g})$ was recorded cuttings planted on $15^{\text {th }}$ June. Comparing the mean values, it is clear from the table that the maximum root weight $(1.47 \mathrm{~g})$ was recorded for cuttings with one bud, followed by cuttings with two buds (0.94 $\mathrm{g}$ ), while minimum root weight $(0.55 \mathrm{~g})$ was noted for cuttings with four buds. Maximum and minimum root weight were observed in cuttings with one bud and cuttings with four buds respectively, which is attributed to the fact that cuttings with one bud produced more number of roots per plant and root thickness which is resulted in heavier roots growth, while cuttings with four buds produced less root as compared to others. According to the mean values for interaction maximum and minimum root weight were recorded for cuttings with one bud and cuttings with four buds planted on $15^{\text {th }}$ July and $15^{\text {th }}$ May respectively. This may be due to the reserved food in the cuttings and their differential response to different environmental conditions as well as maximum and minimum root length and thickness. This work is in agreement with the Jurgen and Kristian, [6] who reported that the onset of axillary bud growth is accelerated in cuttings because of root formation and resulted in higher number of roots plant ${ }^{1}$.

Table 3. Effect of timing and bud numbers on number of roots plant ${ }^{-1}$, primary root length $(\mathrm{cm})$ and root weight $(\mathrm{g})$ of Schefflera propagated through cutting

\begin{tabular}{|c|c|c|c|}
\hline Parameters & Number of roots plant ${ }^{-1}$ & Primary root length $(\mathbf{c m})$ & Root weight (g) \\
\hline \multicolumn{4}{|l|}{ Schefflera cuttings (C) } \\
\hline Cuttings with One bud & $8.16 \mathrm{a}$ & $21.90 \mathrm{a}$ & $1.47 \mathrm{a}$ \\
\hline Cuttings with Two buds & $7.03 \mathrm{~b}$ & $19.93 \mathrm{~b}$ & $0.94 \mathrm{~b}$ \\
\hline Cuttings with Three buds & $6.47 \mathrm{c}$ & $18.42 \mathrm{~b}$ & $0.68 \mathrm{c}$ \\
\hline Cuttings with Four buds & $6.14 \mathrm{bc}$ & $15.02 \mathrm{c}$ & $0.55 \mathrm{c}$ \\
\hline LSD values & 0.241 & 1.695 & 0.106 \\
\hline \multicolumn{4}{|l|}{ Planting time (P) } \\
\hline $15^{\text {th }}$ May & $7.02 \mathrm{~b}$ & $20.11 \mathrm{abc}$ & $0.89 \mathrm{bc}$ \\
\hline $25^{\text {th }}$ May & $6.79 \mathrm{bc}$ & $17.43 \mathrm{bc}$ & $0.88 \mathrm{bc}$ \\
\hline $05^{\text {th }}$ June & $6.52 \mathrm{~cd}$ & $17.26 \mathrm{c}$ & $0.84 \mathrm{bc}$ \\
\hline $15^{\text {th }}$ June & $6.37 \mathrm{~d}$ & $16.38 \mathrm{c}$ & $0.74 \mathrm{c}$ \\
\hline $25^{\text {th }}$ June & $6.65 \mathrm{~cd}$ & $17.26 \mathrm{c}$ & $0.81 \mathrm{bc}$ \\
\hline $05^{\text {th }}$ July & $7.55 \mathrm{a}$ & $21.21 \mathrm{ab}$ & $0.98 \mathrm{~b}$ \\
\hline $15^{\text {th }}$ July & $7.74 \mathrm{a}$ & $22.17 \mathrm{a}$ & $1.24 \mathrm{a}$ \\
\hline LSD values & 0.347 & 3.828 & 0.207 \\
\hline \multicolumn{4}{|l|}{ Interaction $(\mathbf{C} \times \mathbf{P})$} \\
\hline LSD values & 0.653 & NS & NS \\
\hline
\end{tabular}

The dissimilar letters in each column indicate significant differences between them in 5\% level of probability using LSD

\section{Conclusion}

Based on current findings, it can be concluded that cuttings with one bud performed best result for most of the growth parameters as compared to two, three and four buds, cuttings. Among 
different planting dates, $15^{\text {th }}$ July showed best performance for vegetative propagation of Schefflera arboricola at Peshawar Pakistan. Schefflera arboricola cuttings having single bud planted in month of July is recommended best for Peshawar.

\section{Authors' contribution}

Conceived and Designed experiment: $\mathrm{M}$ Sajid, Performed experiment: J Khan, S Hayat \& M Naib, Analyzed data: J Khan \& S Hayat, Write the article: $M$ Sajid, $T$ Muhammad \& K Hayat.

\section{Acknowledgment}

The author hereby would like to thank the co-authors for their contributions in drafting the manuscript. Thanks are extended to the horticulture nursery staff of The University of Agriculture Peshawar for their assistance in the research work.

\section{References}

1- Esteban J (2010). Plant propagation and cultivation. 68- 69

2- Hartmann HT, Kester DE, Davies FT \& Geneve RL (2005) Hartmann and Kester's Plant Propagation: Principles and Practices, New Jersey and London: Prentice-Hall International Ltd.

3- William AH (1979). Plant propagation and cultivation, 96-97. AVI publishing company. Connacticut.

4- Yong KY \& KiSum K (1996). Seasonal variation in rooting ability, plant hormones, carbohydrate, nitrogen starch and soluble sugar contents in cutting of white forsythia (Abeliophyllum distichum, Nakai). J Kor Soc Hort Sci 37: 554-560.

5- Singh P (1983). Studies on propagation of Bougainvillea by stem cutting. Thesis abstract 8(1):47. (hort Abst 53(2): 1190).
6- Jurgen H \& Kristensen K (1990). Axillary bud growth in relation to adventitious root formation in cuttings. Physiologia Plantarum. W J Agri Sci 4 (2): 150-155.

7- Hussein MMM (2008). Studied on the rooting, the consequent plant growth and effect of different plantings dates on the stem cuttings of Thunbergia grandiflora. World J Agri Sci 4(2): 125132.

8- Acker M \& Leutscher KJ (1992). Effect of type of cuttings on heterogeneity and growth of Rosa hybrida and Schefflera arboricola Wageningen Agricultural University, Department of Horticulture, Haagsteeg 3, 6708 PM, Wageningen, Netherlands.

9- Zanin G \& Ponchia G (2002). Sludgecompost trials in cultivation of Pelargonium zonale and Schefflera arboricola Conference [6. Scientific meeting of Italian Horticultural Society Journal Title Atti VI Giornate Scientifiche. 2: 373-374

10- Yadav LP, Bhattacharya AP \& Pandey HS (1980). Effect of season on the rooting of Bougainvillea cuttings. Progressive Hroticulture 9(4): 72-73.

11- Racek M \& Kertesz B (2009). Propagation of selected Clematis cultivar by soft wood cutting "Slovak University of Agriculture, Faculty of Horticulture and Landscape Engineering Tulipanova Agricultura Ştiinţa si practica nr 1-2 (69-70 -71).

12- Elgimabi MN (2008). Effect of Season of Cutting and Humidity on Propagation of (Ixora coccinea" , Biology Division, Faculty of Science, Taif University, Suadia Arabia Advances in Biol 2(5-6): 108-110. 